SHEs: Conference Series 1 (1) (2018) 856-860

\title{
CONNECTION BOOK AND WORKSHEET BASED 2013 CURRICULUM FOR SD TEACHERS IN SURAKARTA
}

\author{
Sri Marmoah, Soegiyanto, Idam Ragil Widianto Atmojo, Roy Ardiansyah
}

Universitas Sebelas Maret

marmuah@staff.uns.ac.id

\section{Article History}

accepted 09/07/2018

approved 01/08/2018

published 17/09/2018

\section{Keywords}

Connection Book,

Worksheet, Teacher

\begin{abstract}
The purpose of this service is to train primary school teachers in Surakarta city to have the ability to optimize the role of a teacher to involve parents and the community in the implementation of learning so that specifically this activity aims to train teachers to have the ability to compile contact books and worksheets. The method used in this service begins the Workshop, Practices, and Implementation. In conducting this training, subjects were asked to work on tests related to the preparation of connection books and worksheets for elementary school teachers. Analysis of the data used is pretest and post-test. The results of this activity were an increase in teacher's knowledge and understanding of the preparation of connection books and worksheets.
\end{abstract}

Social, Humanities, and Education Studies (SHEs): Conference Series https://jurnal.uns.ac.id/shes
p-ISSN 2620-9284

e-ISSN 2620-9292 


\section{PENDAHULUAN}

Kompetensi Guru merupakan indikator seorang guru profesional, kompetensi yang dimaksudkan Menurut Syaiful Sagala (2009: 209) kompetensi merupakan kelayakan untuk menjalankan tugas, kemampuan sebagai faktor penting bagi guru, oleh karena itu kualitas dan produktivitas kerja guru harus mampu memperlihatkan perbuatan profesional yang bermutu. Adapun kompetensi guru (teacher competency) is the ability of a teacher to responsibility perform his or her duties appropriately. Kompetensi guru merupakan kemampuan seseorang guru dalam melaksanakan kewajiban-kewajiban secara bertanggung jawab dan layak (Usman, 2002). Terdapat empat kompetensi guru yang harus diimiliki oleh guru yakni Kompetensi Pedagogik, Komptensi Profesional, Kompetensi Sosial, dan Kompetensi Personal.Keempat kompetensi ini memiliki urgensi dalam pelaksaaan proses pendidikan atau pembelajaran, yakni kompetensi pedagogik akan berpengaruh terhadap kesiapan guru dalam mengajar, komptensi profesional akan berpengaruh kepada kemampuan guru mengalikasikan ilmu, kompetensi sosial berpengaruh kepada kemampuan guru untuk menjalin komunikasi dengan lingkungan siswa atau sekolah, dan kompetensi personal akan berpengaruh terhadap refleksi kepribadian guru di dalam melaksanakan pembelajaran.Pembelajaran yang dimaksud adalah pembelajaran merupakan suatu proses yang sistematis melalui tahap rancangan, pelaksanaan, dan evaluasi (Knirk dan Gustafson, 1986:15).Kegiatan Perancangan, pelaksanaan, dan evaluasi harus dikuatkan dengan kompetensi yang mumpuni yang dimiliki oleh guru.

Permasalahan yang timbul pada beberapa waktu terkahir adalah tentang komunikasi guru dengan orang tua siswa terkait dengan perkembangan belajar siswa di sekolah ataupu dirumah, sehingga terjadi miskomunikasi antara guru dengan siswa sehingga terjadi perbendaan pendapat atau bahkan sampai terjadi aksi-aksi kurang terpuji yang dilakukan orang tua atau bahkan siswa kepada guru, seperti kasus guru Budi di Madura yang harus kehilangan nyawa di tangan murid, dan kejadian pemukulan Kepala Sekolah di salah satu daerah oleh orang tua siswa yang tidak terima anaknya ditegur. Permasalahan yang lain yang menjadi problematika bagu guru adalah soal sumber belajar. Dari sumber anggaran yang terbatas, larangan menggunakan Lembar Kerja Siswa, larangan untuk menarik uang dari siswa padahal di sisi lain guru membutuhkan alat bantu sumber belajar untuk memfasilitasi siswa dalam pelaksanaan proses pembelajaran yang memiliki kualitas, salah satunya adalah pengadaan worksheet. Oleh karena banyaknya larangan yang tidak memungkinkan untuk menggarkan alat bantu ini maka guru diharuskan membuat secara mandiri worksheet yang dibutuhkan.

Solusi yang dapat diberikan adalah dengan mengadakan pelatihan penyusunan Connection Book sebagai solusi untuk membuat komunikasi orang tua dengan guru menjadi lancar tentang perkembangan siswa di sekolah ataupun dirumah, sehingga kejadian miskomunikasi yang menimbulkan hal-hal yang kurang berkenan bisa diminmalisir. Komunikasi menjadi faktor penting dalam pelaksnaan pembelajaran. Komunikasi merupakan tindakan melaksanakan kontak antara pengirim dan penerima, dengan bantuan pesan; pengirim dan penerima memiliki beberapa pengalaman bersama yang memberi arti pada pesan dan simbol yang dikirim oleh pengirim, dan diterima serta ditafsirkan oleh penerima. (Suranto : 2005). Dalam pembelajaran komunikasi yang terjadi harus efektif, Santoso Sastropoetro (Riyono Pratikno : 1987) berkomunkasi efektif berarti bahwa komunikator dan komunikan sama-sama memiliki pengertian yang sama tentang suatu pesan, atau sering disebut dengan "the communication is in tune".

Solusi yang berikutnya adalah pendampingan kepada guru untuk menyusun Worksheet Mandiri sesuai dengan Kurikulum 2013 yang berbasis pada pembelajaran Tematik, sehingga dengan kolaborasi dari pihak akademisi dalam hal ini UNS maka 
akan mampu mendatangkan motivasi tersendiri bagi guru serta diiringi adanya peningkatan kemampuan dan kemauan dalam menyusun Worksheet mandiri sesuai dengan Kurikulum 2013.

Solusi ini bukanlah dua hal yang berbeda, melainkan satu kesatuan karena terikat dengan dua kompetensi yang ada yakni kompetensi sosial dan kompetensi profesional. Kompetensi Sosial dan Profesional memiliki hubungan kausal yang berarti sebab akibat, yakni ketika kemampuan guru dalam menjalin komunikasi dengan orang tua baik maka secara tidak langsung partisipasi orang tua di dalam pembelajaran akan baik yang akan berdampak pada kemampuan guru untuk meningkatkan kemampuan profesional karena mendapatkan dukungan penuh dari orang tua, ataupun sebaliknya.

Connection Book dan Worksheet memberikan dapak yang positif terhadap pelaksanaan pembelajaran. Manfaat dari Connection Book yakni berdasarkan hasil wawancara terhadap guru yang telah menggunakan (uji materi di SD yang bukan mitra pengabdian) adalah (1) Connection Book mampu membuat guru berkomunikasi langsung dengan orang tua siswa melalui siswa, sehingga ketiga komponen pembelajaran terlibat aktif di dalamnya, (2) memebrikan dampak kepada pemahaman orang tua terhadap pembelajaran yang diberikan di sekolah atau memberikan pemahaman kepada guru tentang aktivitas siswa di rumah, (3) Guru menjadi lebih paham tentang hamabatan dan keluhan orang tua ketika mendidik siswa dirumah. Selain Connection Book, Worksheet Mandiri yang diberikan kepada guru juga memberikan dampak yang positif, hal ini berdasarkan hasil wawancara setelah uji coba (di SD yang bukan mitra pengabdian) yakni (1) guru merasa lebih mendapatkan kepercayaan diri, dan (2) guru menjadi lebih mudah mengajarkan materi kepada siswa karena worksheet yang disusun hasil mandiri.

Berdasarkan hasil observasi yang dilakukan pada tanggal 20 Januari s.d. 14 Februari 2018 pada 2 orang kepala sekolah (SD Negeri Dukuhan Kerten dan SD N Purwotomo diperoleh hasil bahwa pengetahuan dan kemampuan guru untuk menyusun Connection Book dan Worksheet sesuai dengan kontek Kurikulum Tematik masih rendah. Dari total guru yang ada di kedua SD mitra sebanyak 35 orang, hanya 2 orang guru atau sekitar $(5,71 \%)$ yang sudah memanfaatkan connection book dan worksheet mandiri walapupun ini belum sesuai dengan konsep yang akan diberikan tetapi upaya ke arah sana sama, namun sisanya sekitar 33 guru belum menggunakan di dalam pembelajarananya. Berdasarkan hasil wawancara dengan kepala sekolah, diperoleh hasil bahwa guru- guru mengalami kesulitan untuk menyusun Connection Book dan Worksheet di dalam pembelajaran Tematik. Hal ini dikarenakan guru belum mengetahui dan memahami konsep dasar tentang urgensi dari Connection Book dan Worksheet Mandiri.

Peran keberadaan connection book dan worksheet mandiri dalam pembelajaran adalah untuk melancarkan kegiatan pembelajaran serta menyamakan persepsi anatara orang tua dan guru tentang perkembangan pengetahuan siswa di dalam pelaksanaan pembelajaran, sehingga dibutuhkan workshop yang dapat membantu mempermudah guru untuk memberikan materi penyusunan connention book dan worksheet mandiri sesuai kurikulum 2013 namun tetap tidak kehilangan esensi dari materi ajar. Berdasarkan hasil observasi pendahuluan yang dilakukan pada beberapa SD mitra tersebut diperoleh hasil bahwa kemampuan guru untuk menyusun Connection Book dan Worksheet mandiri masih rendah sehingga sangat mendesak dilakukan pemberian informasi dan pelatihan pada guru-guru tersebut..

\section{METODE}

Subjek dalam pengabdian ini terdiri guru-guru sekolah dasar yang ada di wilayah administrasi kota Surakarta. Metode yang digunakan dalam pelatihan ini Workshop, Praktik, dan Implementasi. Teknik pengumpulan data menggunakan teknik tes. Teknik analisis yang digunakan menggunakan pre test dan post test.. 


\section{HASIL DAN PEMBAHASAN}

Berdasarkan hasil pretest yang dilakukan sebelum pelaksanaan kegiatan pengabdian menunjukkan bahwa guru-guru sekolah dasar di Surakarta yang terlibat sebagai peserta dalam kegiatan pengabdian dengan jumlah 50 guru yang terdiri dari lima sekolah dasar di kota Surakarta menunjukkan bahwa kemampuan guru dalam menyusun Connection Book dan Worksheet mandiri masih rendah. Hal ini ditunjukkan dari data yang menyatakan bahwa masih terdapat 37 guru atau sebesar $74 \%$ belum tuntas dalam mengerjakan soal pre test terkait dengan penyusunan Connection Book dan Worksheet mandiri di dalam pelaksanaan pembelajaran, atau hanya sekitar 13 guru $(26 \%)$ yang berhasil lulus. Guru yang berhasil lulus dalam pretest di dominasi oleh guru-guru muda yang masih hangat dengan ilmu-ilmu pendidikan terbaru, sedangkan guru-guru senior sedikit kesulitan dalam mengikuti kegiatan yang terkait dengan ilmu-ilmu pendidikan terbaru. Setelah dilaksanakan workshop tentang penyusunan SSP berbasis HOTs kemampuan guru dalam menyusun Connection Book dan Worksheet mandiri meningkat dengan tingkat ketercapaian ketuntasan mencapai $90 \%$ atau sekitar 45 guru berhasil lulus dan sekitar 5 guru yang belum berhasil lulus. Hal ini menunjukkan terjadinya peningkatan sekitar $64 \%$ dari pre test ke post test yakni dari 13 guru menjadi 45 guru atau sekitar 32 guru. Secara grafis dapat dilihat dalam grafik 1.1 berikut:

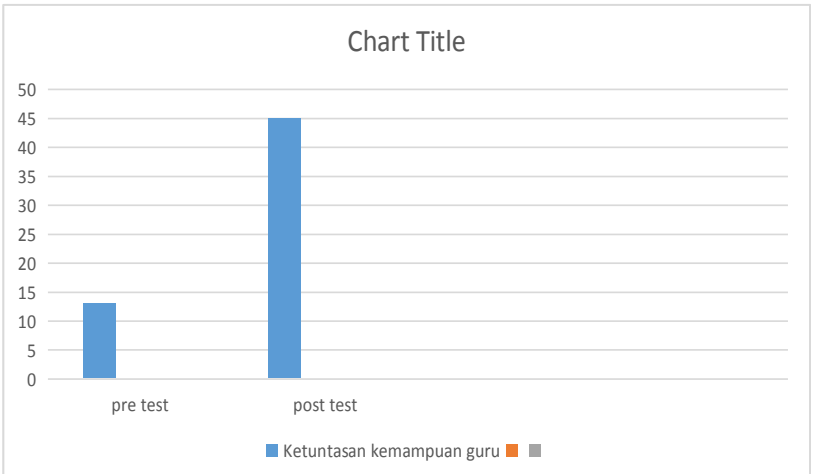

\section{Gambar 1.1 Grafik Hasil perbandingan pre test dan post test kemampuan guru SD}

Berdasarkan hasil pretest dan posttest yang telah dilakukan ditemukan fakta bahwa pelatihan yang dilakukan memberikan dampak yang signifikan terhadap kompetensi guru. Pelatihan yang diberikan tentang penyusunan Connection Book dan Worksheet mandiri memberikan dampak yang signifikan terhadap kemampuan guru dalam hal penyusunan Connection Book dan Worksheet mandiri. Kegiatan workshop atau pelatihan dengan mendatangkan narasumber ahli yang merupakan pakar di bidang tersebut secara tidak langsung sudah memberikan dampak yang positif melalui proses komunikasi yang baik. Sebagaimana dijelaskan dalam Rosmawaty (2010) bahwa komunikasi kelompok adalah komunikasi dalam kelompok kecil orang, dengan tujuan antara lain untuk berbagi informasi, membantu mengembangkan gagasan bahkan membantu untuk memecahkan masalah, baik secara formal maupun tidak formal. Situasi formal yang dibangun ketika pelaksanaan Pelatihan atau Workshop akan membantu menyelesaikan permasalahan yang dihadapi oleh guru dalam hal penyusunan Connection Book dan Worksheet mandiri. 
SHEs: Conference Series 1 (1) (2018) 856-860

\section{SIMPULAN}

Berdasarkan dari hasil kegiatan pelatihan atau workshop dapat disimpulkan bahwa dengan pelaksanaan workshop tentang penyusunan Connection Book dan Worksheet mandiri dapat meningkatkan kemampuan guru dalam menyusun Connection Book dan Worksheet mandiri yang akan digunakan dalam pelaksanaan pembelajaran. Simpulan ini didapatkan dari hasil analisis pre test dan post test yang dilakukan ketika pelaksanaan kegiatan..

\section{DAFTAR PUSTAKA}

Knirk, F. G. dan Gustafson, K.L. 1986. Instructional Technology A Systematic. Approch to Education. New York : Hlt Rinehart and Winston

Riyono, Pratikto. 1987.Berbagai Aspek Ilmu Komunikasi. Remadja Karya: Bandung Rosmawanty HP. (2010). Mengenal Ilmu Komunikasi. Widya Padjadjaran Sagala,Syaiful . 2009. Konsep dan Makna Pembelajaran. Bandung : CV. ALFABETA Suranto, AW .2005, Komunikasi Perkantoran; Prinsip Komunikasi untuk Meningkatkan Kinerja Perkantoran, Cetakan I. Depok, Yogyakarta:Media Wacana.

Usman, Moh. Uzer .2002. Menjadi Guru Profesional, PT. Remaja Rosda Karya: Bandung. 